\title{
Partial Oxidation of Methane over M-Sb-Te-O $(M=$ Transition Metal) Catalysts
}

\author{
Jong Won Lee, Jin Kwon Lee, Seung Koo Cho, ${ }^{\dagger}$ Jin-Seung Jung, ${ }^{\ddagger}$ and Sung Han Lee \\ Department of Chemistry, Ionsei Lniversitw, Honj 220-710, Korea \\ "Department of Chemistry, Sangij Lniversity, Wonju 220-702, Korea \\ ${ }^{\ddagger}$ Department of Chemistry, Kangnthy National Lniversitw, Kangnung 210-320, Korea \\ Received November $t_{1} 2003$
}

Key Words : Metal antimony telluride. Partial oxidation of methane

The catalytic partial oxidation of methane has received a great deal of attention for the utilization of natural gas during the last 20 years. The degree of $\mathrm{CH}_{4}$ oxidation required depends on the process. ${ }^{1.2}$ In the catalytic combustion of $\mathrm{CH}_{4}$ the objective is full oxidation to $\mathrm{CO}_{3}$. For chemicals productions the end products are $\mathrm{CH}_{3} \mathrm{OH} . \mathrm{HCHO}$ and $\mathrm{HCOOH}$ in the formation of syngas the target is $\mathrm{CO}$. while in the oxidative coupling the desired products are $\mathrm{C}_{2} \mathrm{H}_{4}$ and $\mathrm{C}_{3} \mathrm{H}_{6}$. Oxidative coupling of methane has been recognized as a promising route for the direct conversion of methane to ethane or ethylene. In general. metal oxides show catalytic activity for the oxidative coupling of methane. Adsorbed oxygen and lattice oxygen ions on the surface of metal oxides play an important role on the activation of methane. Although the catalytic reaction mechanisms for the oxidative coupling of methane vary with the metal oxide cataly'sts. it is generally accepted that methyl radicals are produced via the dehydrogenation of methane on the surface of metal oxide catalyst and the resulting methyl radicals are coupled to ethane on the surface or in the gas phase.

A variety of solid materials have been examined as catalysts for the oxidative coupling of methane to identify' suitable catalysts which can give high yield of $\mathrm{C}_{2}$-hydrocarbons in the reaction. However few Te-containing metal oxides have been tested as catalysts for the reaction until now. In recent years. it has been reported that metal tellurides show excellent catalytic performance in the ammoxidation and oxidation of hydrocarbons. ${ }^{3-5}$ We reported in the previous papers that the oxygen-pretreated $\mathrm{LiSbTe}_{2}$ and $\mathrm{Ni}_{3} \mathrm{Sb}_{2} \mathrm{Te}_{6}$ catalysts showed catalytic activity and $\mathrm{C}_{\mathbf{2}}$-selectivity in the partial oxidation of methane ${ }^{67}$ In this work. we prepared various metal tellurides such as $\mathrm{Cr}_{3} \mathrm{Sb}_{2} \mathrm{Te}_{6} . \mathrm{Mn}_{3} \mathrm{Sb}_{2} \mathrm{Te}_{6}$. $\mathrm{Fe}_{3} \mathrm{Sb}_{2} \mathrm{Te}_{6}, \mathrm{Co}_{3} \mathrm{Sb}_{2} \mathrm{Te}_{6}$. and $\mathrm{Ni}_{3} \mathrm{Sb}_{2} \mathrm{Te}_{6}$ and examined them as catalysts for the partial oxidation of methane in the temperature range of 670 to 730 at atmospheric pressure.

\section{Experimental Section}

$\mathrm{M}_{3} \mathrm{Sb}_{2} \mathrm{Te}_{6}(\mathrm{M}=\mathrm{Cr}$. Mn. Fe. Co. Ni) compounds were prepared by using a rapid precipitation metathesis reaction between the Zintl material $\mathrm{K}_{3} \mathrm{SbTe}_{j}$ and the transition-metal salt in solution. as described by Jung et af ${ }^{8.5}$ The ternary

\footnotetext{
To whom comespondence should be addressed. e-mail: shl2238 àdragon yonsei.ac.kr
}

Zintl phase $\mathrm{K}_{2} \mathrm{SbTe}_{3}$ prepared from a direct combination of the elements is described as a polar metallic solid in which the bonding gives rise to a substantial amount of ionic bonding character. Therefore. $\mathrm{K}_{3} \mathrm{SbTe}_{3}$ is soluble in water by the reaction: $\mathrm{K}_{2} \mathrm{SbTe}_{3}(\mathrm{~s}) \rightarrow 3 \mathrm{~K}^{+}+\mathrm{SbTe}_{2}{ }^{3-}$, and the Zintl solution allows subsequent metathesis reaction with transition-metal salt to form amorphous material due to the transfer of electrons from the $\mathrm{SbTe}_{3}{ }^{3-}$ anion to the metal cation according to the reaction: $3 \mathrm{M}^{2^{-}}+2 \mathrm{SbTe}_{3}{ }^{3-} \rightarrow$ $\mathrm{M}_{3}\left(\mathrm{SbTe}_{3}\right){ }_{2}(s){ }^{10}$ A stoichiometric quantity of $\mathrm{K}_{2} \mathrm{SbTe}_{2}$ aqueous solution was added slowly while stirring the transitionmetal salt solution. A precipitate was formed immediately. It was then separated by solution filtration. washed with deionized water and acetone. and dried in a vacuum oven. Sample manipulations were performed under an oxygen free dry box.

The catalytic reactions were performed in a conventional gas-flow reactor operated at atmospheric pressure. The reactor was made of quartz tubing with $0.45 \mathrm{~cm}$ inner diameter and $20 \mathrm{~cm}$ length. The powdered catalyst was held between two silica wool plugs in the middle of the reactor. The amount of catalyst loaded into the reactor was $200 \mathrm{mg}$. The reactor was kept in a vertical tubular furnace and a Ktype thermocouple sealed with an alumina tube was contacted with the outside wall of the reactor next to the catalyst bed. Both reaction mixtures containing $\mathrm{CH}_{4} / \mathrm{O}_{3} / \mathrm{He}$ and $\mathrm{CH}_{4} /$ $\mathrm{O}_{2} / \mathrm{H}_{2} \mathrm{O}(\mathrm{g}) / \mathrm{He}$ were employed for the partial oxidation of methane. The feed flow rates at ambient conditions were $\mathrm{CH}_{4} / \mathrm{O}_{2} / \mathrm{He}=6 / 1 / 13 \mathrm{~cm}^{3} / \mathrm{min}$ and $\mathrm{CH}_{4} / \mathrm{O}_{2} / \mathrm{H}_{2} \mathrm{O}(\mathrm{g}) / \mathrm{He}=6 / 1 /$ $8 / 5 \mathrm{~cm}^{3} / \mathrm{min}$. Flow rates of gases were controlled by a needle valve and a electronic mass flow controller. The purity of gaseous oxygen. methane. and helium was greater than $99.99 \%$. Steam was produced from deionized water pumped into the reactor by a syrringe injection pump. The lines from the exit of the syringe up to the inlet of the reactor were heated at $150^{\circ} \mathrm{C}$ A cold trap was placed at the reactor exit to remove water vapor from the gaseous mixture. Gaseous reactants and products were analyzed by an on-line gas chromatography equipped with a thermal conductivity detector and a flame ionization detector. Gas compositions were calculated using an external standard gas mixture. $\mathrm{M}_{3} \mathrm{Sb}_{2} \mathrm{Te}_{6}$ compounds were treated in a flow of gaseous oxygen $\left(10 \mathrm{~cm}^{3} / \mathrm{min}\right)$ at $600^{\circ} \mathrm{C}$ for $1 \mathrm{~h}$ before each activity measurement. After the $\mathrm{O}_{2}$-treatment of catalyst. the reactor was cooled to room temperature. helium gas was passed to 
remove oxygen gas remaining in the reactor. then the reactor temperature was ramped to the desired value using a programmable temperature controller and finally a reaction mixture was fed over the catalyst. The catalytic reactions were carried out in the temperature range from 670 to 730 "C. The conversion of methane was calculated from the amounts of products generated and the methane introduced in the feed strean. The selectivities were calculated on the basis of the conversion of methane to each product and the yield was obtained from the methane conversion and the selectivity to each product. The methane conversion and product selectivities were typically compared after 1 h timeon-strean. Thermogravinietry (TG) and X-ray powder diffraction (XRD) analyses were performed for the catalysts.

\section{Results and Discussion}

Oxygen-treated $\mathrm{M}_{3} \mathrm{Sb}_{2} \mathrm{Te}_{6}$ compounds showed catalytic activity for the partial oxidation of methane. Because amorphous $\mathrm{M}_{3} \mathrm{Sb}_{2} \mathrm{Te}_{6}$ compounds were treated in a flow of gaseous oxygen at $600^{\circ} \mathrm{C}$ prior to the reaction. the catalysts are substantially mixed oxides, representing as M-Sb-Te-O. When the reaction mixtures containing $\mathrm{CH}_{4} / \mathrm{O}_{7} / \mathrm{He}$ and $\mathrm{CH}_{4} /$ $\mathrm{O}_{2} / \mathrm{H}_{2} \mathrm{O} / \mathrm{He}$ were fed over the catalysts in the temperature range of 670 to $730^{\circ} \mathrm{C}$, the major products were $\mathrm{CO}, \mathrm{CO}$. $\mathrm{C}_{3} \mathrm{H}_{4}, \mathrm{C}_{3} \mathrm{H}_{6}$. and $\mathrm{C}_{3}$ hydrocarbons. Table 1 shows the methane conversion and product selectivities of several catalysts when the reaction mixture $\mathrm{CH}_{4} / \mathrm{O}_{2} / \mathrm{He}$ was fed in the temperature range of $670-730{ }^{\circ} \mathrm{C}$ at atmospheric pressure. Among the catalysts tested, both the $\mathrm{Cr}-\mathrm{Sb}-\mathrm{Te}-\mathrm{O}$ and $\mathrm{Fe}-\mathrm{Sb}-$ $\mathrm{Te}-\mathrm{O}$ revealed negligible $\mathrm{C}_{2}$-selectivities and methane conversions $(\leq 2 \%)$ for the reaction. The $\mathrm{C}_{2}$-selectivity declined with increasing temperature while the methane conversion increased with increasing temperature. The $\mathrm{Ni}$ $\mathrm{Sb}-\mathrm{Te}-\mathrm{O}$ catalyst showed the best $\mathrm{C}-\mathrm{yield}$ of $5.9 \%$ with a $\mathrm{C}_{-}$-selectivity of $40 \%$ at $730{ }^{\circ} \mathrm{C}$. The $\mathrm{Co}-\mathrm{Sb}-\mathrm{Te}-\mathrm{O}$ cataly st showed $\mathrm{C}_{2}-\mathrm{selectivities}$ of $50-68 \%$ with $\mathrm{C}-\mathrm{yields}$ of 3.7 $4.8 \%$ in the temperature range of 670 to $730{ }^{\circ} \mathrm{C}$.

When steam was added into the reaction mixture $\mathrm{CH}_{4} / \mathrm{O}_{4}$ He. $\mathrm{C}_{2}$-selectivity and methane conversion were significantly

Table 1. Methane conversion and product selectivities of oxygentreated $\mathrm{M}_{3} \mathrm{Sb}_{2} \mathrm{Te}_{\mathrm{o}}$ catalysts for the partial oxidation of methane

\begin{tabular}{|c|c|c|c|c|c|c|c|}
\hline \multirow{2}{*}{ Catalyst } & \multirow{2}{*}{$\mathrm{T}\left({ }^{\circ} \mathrm{C}\right)$} & \multicolumn{5}{|c|}{ Product Selectivity (\%) } & \multirow{2}{*}{$\begin{array}{l}\text { Methante } \\
\text { Conversion } \\
(\%)\end{array}$} \\
\hline & & $\mathrm{CO}$ & $\mathrm{CO}_{2}$ & $\mathrm{C}_{2} \mathrm{H}_{4}$ & $\mathrm{C}_{2} \mathrm{H}_{6}$ & $\mathrm{C}_{3}$ & \\
\hline \multirow{3}{*}{$\mathrm{Mn}_{3} \mathrm{Sb}_{2} \mathrm{Te}_{6}$} & 670 & 42.5 & 25.3 & 16.3 & 15.5 & 0.4 & 7.9 \\
\hline & 700 & 33.6 & 40.2 & 16.9 & 8.6 & 0.7 & 14.4 \\
\hline & 730 & 31.1 & 41.0 & 17.8 & 7.7 & 2.4 & 16.2 \\
\hline \multirow{3}{*}{$\mathrm{CO}_{3} \mathrm{Sb}_{2} \mathrm{Te}_{\mathrm{r}}$} & 670 & 18.2 & 12.4 & 44.8 & 22.8 & 1.8 & 5.5 \\
\hline & 700 & 16.7 & 23.1 & 39.3 & 18.4 & 2.5 & 8.4 \\
\hline & 730 & 15.3 & 28.8 & 34.1 & 16.7 & 5.1 & 9.5 \\
\hline \multirow{3}{*}{$\mathrm{Ni}_{\xi} \mathrm{Sb}_{2} \mathrm{Te}_{6}$} & 670 & 17.9 & 15.1 & 39.2 & 27.8 & 0 & 7.2 \\
\hline & 700 & 15.4 & 31.6 & 360 & 14.9 & 2.1 & 11.1 \\
\hline & 730 & 130 & 45.0 & 30.5 & 9.5 & 2.0 & 14.7 \\
\hline
\end{tabular}

Catalyst weight: $200 \mathrm{mg}$. reaction teed: $\mathrm{CH}_{4} \mathrm{O}_{2} \mathrm{He}=6: 1: 13 \mathrm{~cm}^{2}: \mathrm{min}$.
Table 2. Methane conversion and product selectivities of oxygentreated $\mathrm{M}_{3} \mathrm{Sb}_{2} \mathrm{Te}_{6}$ catalysts in the reaction mixture containing $\mathrm{CH}_{4}$ $\mathrm{O}_{2} / \mathrm{H}_{2} \mathrm{O}(\mathrm{g}) / \mathrm{He}$

\begin{tabular}{|c|c|c|c|c|c|c|c|}
\hline \multirow[b]{2}{*}{ Catalyst } & \multirow[b]{2}{*}{$\mathrm{T}\left({ }^{\circ} \mathrm{C}\right)$} & \multicolumn{5}{|c|}{ Product Selectivity (\%) } & \multirow{2}{*}{$\begin{array}{c}\text { Methane } \\
\text { Conversion } \\
(\%)\end{array}$} \\
\hline & & $\mathrm{CO}$ & $\mathrm{CO}_{2}$ & $\mathrm{C}_{2} \mathrm{H}_{4}$ & $\mathrm{C}_{2} \mathrm{H}_{5}$ & $C_{3}$ & \\
\hline \multirow{3}{*}{$\mathrm{Cr}_{3} \mathrm{Sb}_{2} \mathrm{Te}_{6}$} & 670 & 34.1 & 0 & 35.3 & 25.1 & 5.3 & 3.3 \\
\hline & 700 & 30.5 & 1.3 & 45.9 & 20.1 & 2.2 & 7.9 \\
\hline & 730 & 29.7 & 3.0 & 51.3 & 13.7 & 2.3 & 9.2 \\
\hline \multirow{3}{*}{$\mathrm{Mn}_{3} \mathrm{Sb}_{2} \mathrm{Te}_{6}$} & 670 & 25.6 & 0 & 40.2 & 31.2 & 3.0 & 7.0 \\
\hline & 700 & 28.6 & 0 & 42.3 & 24.2 & 4.9 & 10.9 \\
\hline & 730 & 32.1 & 1.9 & 42.8 & 15.7 & 7.5 & 13.6 \\
\hline \multirow{3}{*}{$\mathrm{Fe}_{3} \mathrm{Sb}_{2} \mathrm{Te}_{6}$} & 670 & - & - & - & - & - & $<1$ \\
\hline & 700 & 20.4 & 18.5 & 25.8 & 35.1 & 0.2 & 1.5 \\
\hline & 730 & 18.3 & 26.8 & 35.2 & 18.4 & 1.3 & 2.6 \\
\hline \multirow{3}{*}{$\mathrm{Co}_{3} \mathrm{Sb}_{2} \mathrm{Te}_{6}$} & 670 & 18.5 & 0 & 41.0 & 35.5 & 5.6 & 6.7 \\
\hline & 700 & 18.4 & 0.9 & 46.4 & 28.7 & 5.6 & 10.1 \\
\hline & 730 & 15.4 & 2.3 & 56.7 & 17.1 & 8.5 & 13.5 \\
\hline \multirow{3}{*}{$\mathrm{Ni}_{3} \mathrm{Sb}_{2} \mathrm{Te}_{6}$} & 670 & 38.7 & 7.5 & 28.1 & 24.4 & 1.3 & 7.7 \\
\hline & 700 & 30.6 & 9.3 & 35.5 & 23.1 & 1.5 & 12.1 \\
\hline & 730 & 20.9 & 15.8 & 43.1 & 18.4 & 1.8 & 13.8 \\
\hline
\end{tabular}

Catalyst weight: 200 mg. reaction feed: $\mathrm{CH}_{4} \mathrm{O}_{2} \mathrm{H}_{2} \mathrm{O}(\mathrm{g}) \mathrm{He}=6: 1: 85$ $\mathrm{cm}^{3}$ min.

increased. Table 2 gives the methane conversion and product selectivities of the cataly sts when the reaction mixture $\mathrm{CH}_{4} /$ $\mathrm{O}_{2} / \mathrm{H}_{2} \mathrm{O}(\mathrm{g}) / \mathrm{He}$ was fed in the temperature range of 670 to $730^{\circ} \mathrm{C}$. The $\mathrm{Co}-\mathrm{Sb}-\mathrm{Te}-\mathrm{O}$ catalyst showed the $\mathrm{C}_{2}$-selectivity of $73.8 \%(56.7 \%$ to ethylene and $17.1 \%$ to ethane) with a methane conversion of $13.5 \%$ at $730{ }^{\circ} \mathrm{C}$. which is rather appreciable. Although the $\mathrm{Cr}-\mathrm{Sb}-\mathrm{Te}-\mathrm{O}$ catalyst showed poor activity and negligible $\mathrm{C}_{2}$-selectivity in the reaction feed of $\mathrm{CH}_{4} / \mathrm{O}_{2} / \mathrm{He}$. in the presence of water vapor it showed a good $\mathrm{C}_{2}$-selectivity of $65 \%$ with a $\mathrm{C}$-yield of $6 \%$ at $730{ }^{\circ} \mathrm{C}$. It is noted that the formation of $\mathrm{CO}_{2}$ over the $\mathrm{Cr}-\mathrm{Sb}-\mathrm{Te}-\mathrm{O}, \mathrm{Mn}-$ $\mathrm{Sb}-\mathrm{Te}-\mathrm{O}$, and $\mathrm{Co}-\mathrm{Sb}-\mathrm{Te}-\mathrm{O}$ catalysts is negligible in the presence of steam.

Thermogravimetry analysis was performed for amorphous $\mathrm{Cr}_{2} \mathrm{Sb}_{2} \mathrm{Te}_{6}, \mathrm{Fe}_{3} \mathrm{Sb}_{2} \mathrm{Te}_{6}, \mathrm{Co}_{3} \mathrm{Sb}_{2} \mathrm{Te}_{6}$ and $\mathrm{Ni}_{2} \mathrm{Sb}_{2} \mathrm{Te}_{6}$ compounds at a heating rate of $10^{\circ} \mathrm{C} / \mathrm{min}$ in the temperature range of 25 $1000^{\circ} \mathrm{C}$ in a flow of $\mathrm{O}_{2}(20 \%) / \mathrm{Ar}$ mixture and the results are shown in Figure 1. Weight gains occur in the temperature range of $150-750{ }^{\circ} \mathrm{C}$. which means that a lot of gaseous oxygen is chemisorbed on the catalyst surface. leading to an oxidation of catalyst. In general. metal tellurides are readily oxygenated in the presence of gaseous oxygen and the present result is in agreement with those by other investigators ${ }^{6.11 .12}$ The cause of the weight decrease above $750{ }^{\circ} \mathrm{C}$ is mainly the vaporization of tellurium. As shown in Figure 1. the weight uptake of $\mathrm{Fe}_{2} \mathrm{Sb}_{2} \mathrm{Te}_{6}$ begins from $150^{\circ} \mathrm{C}$. while those of the other samples occur above $200{ }^{\circ} \mathrm{C}$. The weight uptake of $\mathrm{Cr}_{2} \mathrm{Sb}_{2} \mathrm{Te}_{6}$ was much less than those of the other samples. Both the $\mathrm{O}_{2}$-treated $\mathrm{Fe}_{3} \mathrm{Sb}_{2} \mathrm{Te}_{6}$ and $\mathrm{Cr}_{3} \mathrm{Sb}_{2} \mathrm{Te}_{6}$ catalysts showed poor activities for the partial oxidation of methane. which enables us to consider that the catalytic activity and $\mathrm{C}_{2}$-selectivity is closely related with the extent of oxygenation of $\mathrm{M}_{2} \mathrm{Sb}_{2} \mathrm{Te}_{6}$ by the $\mathrm{O}_{2}$-treatment. 


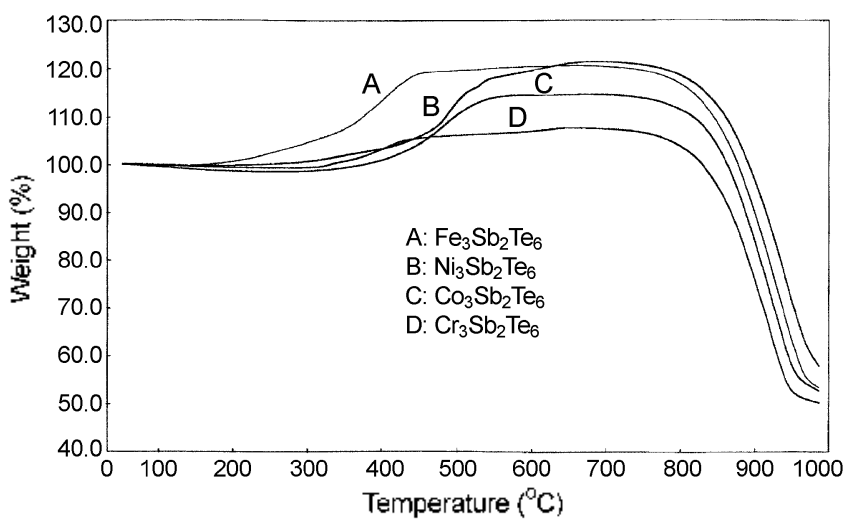

Figure 1. TGi curves of several $M_{3} S_{2} b_{2} T c_{1}$ in a thot of $\left.0: 20 \%\right) / \Lambda r$ gas mixture.

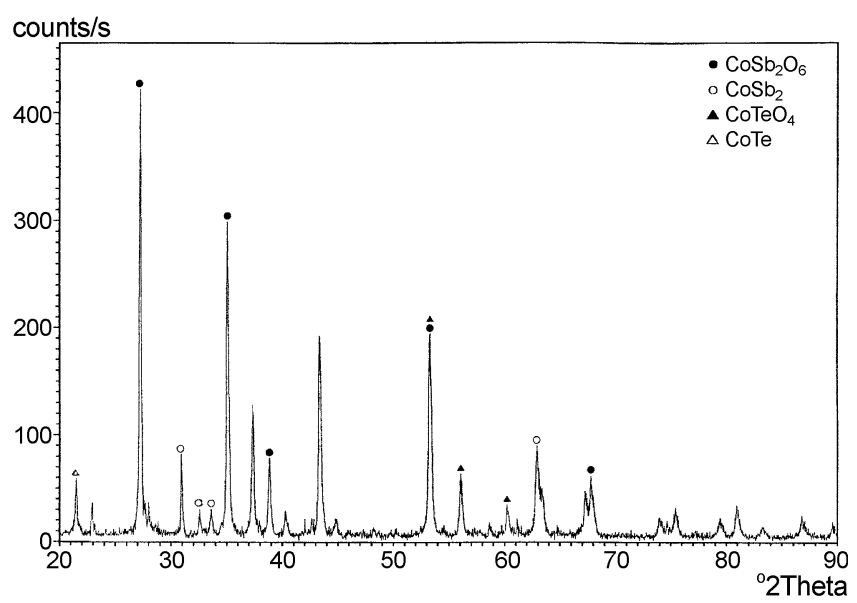

Figure 2. X-ray diffiraction pattern of the oxyen-treated $\mathrm{Co}_{3} \mathrm{Sh}_{2} \mathrm{Tc}_{6}$ catalyst.

In the oxidative coupling of methane over metal oxide catalysts, methyl radicals must be primarily produced by the abstraction of a hydrogen atom from methane which is chemisorbed on active oxygen ions on the catalyst surface. Many investigators have reported that active oxygen species such as $\mathrm{O}^{-}, \mathrm{O}_{2}^{-}$, and $\mathrm{O}_{2}^{2-}$ can be generated on oxygen vacancy or basic sites in metal oxide catalysts ${ }^{13-15}$ and the stability of active oxygen species formed on the catalyst surface depends on the basicity of metal oxide and the existence of suitable sites.' As listed in Tables 1 and 2, the oxygen-treated $\mathrm{M}_{3} \mathrm{Sb}_{2} \mathrm{Te}_{6}$ catalysts were active for the reactions, implying active oxygen ions to be formed on the catalysts. XRD results of the catalysts showed that amorphous $\mathrm{M}_{3} \mathrm{Sb}_{2} \mathrm{Te}_{6}$ compounds were decomposed and oxidized to form oxides during the oxygen treatment, indicating the catalysts to be mixed oxides. Figure 2 presents the $\mathrm{X}$-ray diffraction pattern of the $\mathrm{O}_{2}$-treated $\mathrm{Co}_{3} \mathrm{Sb}_{2} \mathrm{Te}_{6}$ catalyst which was active for the reaction, in which the presence of $\mathrm{CoSb}_{2} \mathrm{O}_{6 .}$. $\mathrm{CoSb}_{2}, \mathrm{CoTeO}_{4}$, and $\mathrm{CoTe}_{\mathrm{T}}$ phases is observed. Among the phases identified, $\mathrm{CoSb}_{2} \mathrm{O}_{6}$ and $\mathrm{CoTeO}_{4}$ oxides are considered to be active components for the oxidative coupling of methane.

Figure 3 presents the XRD result for the $\mathrm{O}_{2}$-treated $\mathrm{Ni}_{3} \mathrm{Sb}_{2} \mathrm{Te}_{6}$ catalyst, showing the presence of $\mathrm{NiO}, \mathrm{NiSb}_{2} \mathrm{O}_{6}$.

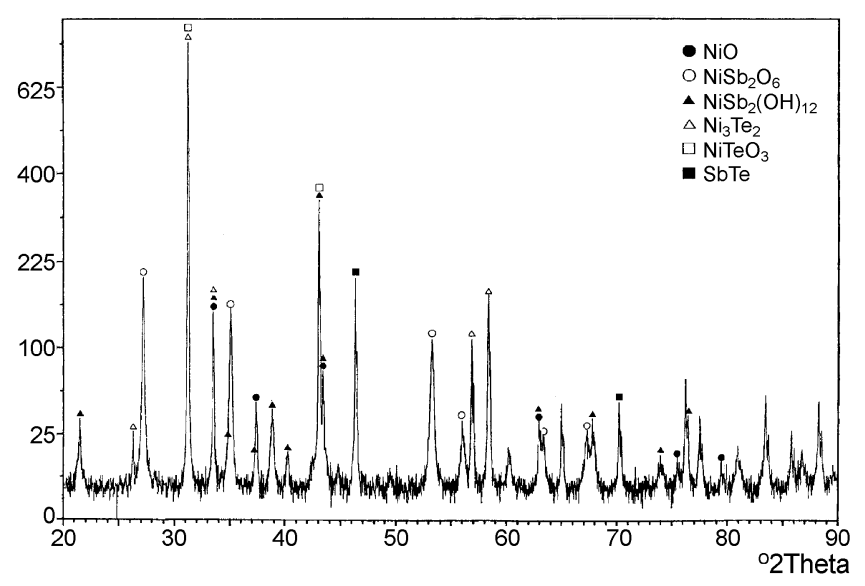

Figure 3. X-ray diftraction pattern of the oxygen-treated $\mathrm{Ni}_{3} \mathrm{Sb}_{2} \mathrm{Te}_{6}$ catalyst.

and $\mathrm{Ni} \mathrm{leO}_{3}$ phases. We measured methane conversions and selectivities of $\mathrm{NiO}, \mathrm{Sb}_{2} \mathrm{O}_{3}, \mathrm{TeO}_{2}$, and $\mathrm{NiSb}_{2} \mathrm{O}_{6}$ catalysts for the partial oxidation of methane under the reaction conditions. At $700{ }^{\circ} \mathrm{C}$. both $\mathrm{NiO}$ and $\mathrm{TeO}_{2}$ catalysts did not produce ethylene and ethane, $\mathrm{Sb}_{2} \mathrm{O}_{3}$ catalyst showed a $\mathrm{C}_{2}$ selectivity of $30 \%$ at a methane conversion of $5 \%$, and $\mathrm{NiSb}_{2} \mathrm{O}_{6}$ catalyst showed a $\mathrm{C}_{2}$ selectivity of $51 \%$ at a methane conversion of $8 \%$. We could not measure the catalytic activity of $\mathrm{Ni}^{\prime} \mathrm{COO}_{3}$. We tried to prepare $\mathrm{Ni}^{\prime} \mathrm{CeO}_{3}$ pahse from both the oxidation of Ni-le mixture at $600{ }^{\circ} \mathrm{C}$ and the direct solid-state reaction between $\mathrm{NiO}$ and $\mathrm{TeO}_{2}$ at 700 ' $\mathrm{C}$. but various nickel-tellurium oxide phases such as $\mathrm{Ni}^{\prime} \mathrm{e}_{2} \mathrm{O}_{5}, \mathrm{Ni}_{2} \mathrm{Je}_{3} \mathrm{O}_{4}$, and $\mathrm{Ni}^{\prime} \mathrm{leO} \mathrm{O}_{3}$ were produced and thus, the synthesis and activity of monophase $\mathrm{Ni}^{\prime} \mathrm{CO}_{3}$ catalyst remain to be further studied. The nickel-tellurium oxide mixture exhibited a methane conversion of $4 \%$ with a $\mathrm{C}_{2}$ selectivity of $23 \%$ for the reaction at 700 " $\mathrm{C}$. The results indicate that these catalysts are less active and selective than the $\mathrm{O}_{2}-$ pretreated $\mathrm{Ni}_{3} \mathrm{Sb}_{2} \mathrm{le}_{6}$ catalyst.

Several investigators have recently reported that $\mathrm{M}-\mathrm{Sb}-\mathrm{O}$ such as $\mathrm{NiSbO}_{x}, \mathrm{GaSbO}_{n}, \mathrm{VSbO}_{x}, \mathrm{MoSbO}_{x}, \mathrm{FeSbO}_{\mathrm{n}}$ and $\mathrm{ReSb}_{2} \mathrm{O}_{4}$ showed appreciable activities for the ammoxidation of hydrocarbons. ${ }^{16-20}$ ln the M-Sb-O catalysts for the ammoxidation of hydrocarbons, hydrocarbon molecules are activated by metal antimonate and antimony is considered to facilitate the abstraction of hydrogen from hydrocarbon molecules. The results give an feasibility that $\mathrm{M}-\mathrm{Sb}-\mathrm{O}(\mathrm{M}-$ transition metal) phases act as active components in the partial oxidation of methane. In the previous paper, we showed that $\mathrm{NiSb}_{2} \mathrm{O}_{6}$ catalyst was active and selective for the oxidative coupling of methane. On the other hand, Tecontaining compounds are also active catalysts for the ammoxidation of propane. ${ }^{+} \mathrm{MoVNbTeO}$ catalyst was found to show excellent catalytic performance for the selective ammoxidation and oxidation of propane to acrylonitrile and acrylic acid, in which $\mathrm{MTe}_{2} \mathrm{O}_{3}(\mathrm{M}-\mathrm{Mo}, \mathrm{V}, \mathrm{Nb})$ with a hexagonal bronze structure is an active component for the reactions. ${ }^{4.5}$ In the previous paper, ${ }^{7}$ we suggested from the XRD and XPS results of the Ni-Sb-Te-O catalyst that $\mathrm{NiTeO}_{3}$ containing some higher valent $\mathrm{Ni}$ ions was a selec- 


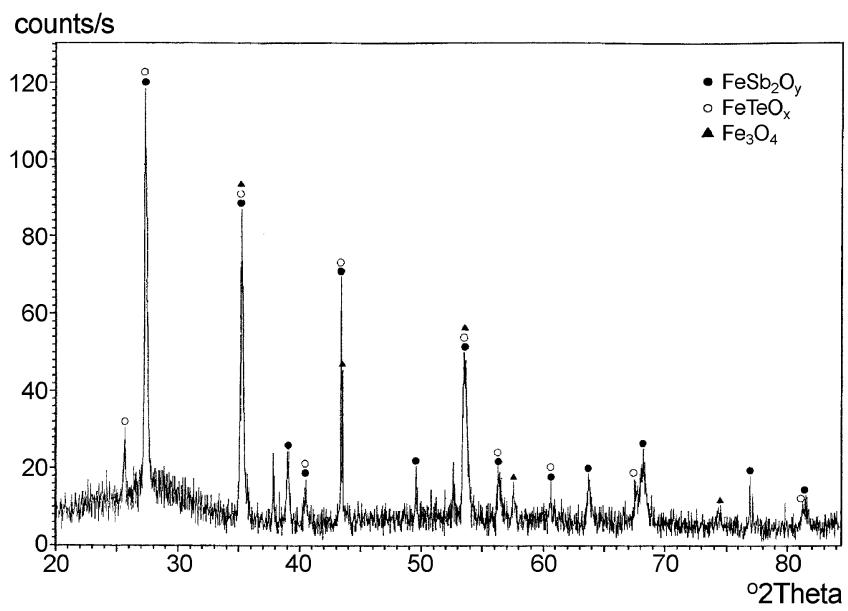

Figure 4. X-ray dilliaction pattern of the oxygen-treated liessb $\mathrm{le}_{6}$ catalyst.

tive phase in the oxidative coupling of methane. The results support that $\mathrm{M}-\mathrm{Ce}-\mathrm{O}$ phases formed on the catalyst surface can act as active components for the partial oxidation of methane. Although the respective roles of the two phases are not yet fully understood. it is believed that their coexistence is needed to obtain effective catalyst for the reaction.

Figure 4 presents the $\mathrm{X}$-ray diffraction pattern of $\mathrm{O}_{2}$ treated $\mathrm{He}_{3} \mathrm{Sb}_{2} \mathrm{le}_{6}$ catalyst which showed poor activity for the partial oxidation of methane. The XRD pattern exhibits the presence of magnetite $\left(\mathrm{Fe}_{3} \mathrm{O}_{4}\right), \mathrm{Fe}_{2} \mathrm{Je}_{3} \mathrm{O}_{6}$, and $\mathrm{FeSb}_{2} \mathrm{O}_{4}$ $(4 \leq \mathrm{y} \leq 7)$ phases. In the reaction feed of $\mathrm{CH}_{4} / \mathrm{O}_{2} / \mathrm{He}$ over Fe-Sb-le-O catalyst, the major product was $\mathrm{CO}_{2}$. Magnetite catalyst is known to be active for the water-gas shift reaction $\left(\mathrm{CO}(\mathrm{g})+\mathrm{H}_{2} \mathrm{O}(\mathrm{g}) \rightarrow \mathrm{CO}_{2}(\mathrm{~g})+\mathrm{H}_{2}(\mathrm{~g})\right)$, but inactive for the oxidative coupling of methane. Poor activity of $\mathrm{Fe}-\mathrm{Sb}-\mathrm{Te}-\mathrm{O}$ catalyst in the partial oxidation of methane is believed to be due to the presence of magnetite phase on the catalyst surface.

As given in rable 2 , the $\mathrm{C}_{2}$-selectivity and methane conversion were matkedly increased when steam was added to the reaction mixture $\mathrm{CH}_{4} / \mathrm{O}_{2} / \mathrm{He}$. A comparison between the results given in Tables $\mathrm{I}$ and 2 indicates that the production of carbon oxides markedly decreases in the presence of steam. which implies that steam inhibits the formation of carbon oxides. The role of steam on the catalytic reaction seems to be related to the formation of a stable concentration of hydroxyl species on the surface instead of the oxygen species which are more likely to produce carbon oxides. The need for the presence of steam requires further research to be understood and studies on the detailed reaction mechanism over the present specimens are currently in progress.

Acknowledgment. This work was supported by research funds from Yonsei University in 2002.

\section{References}

1. Oyama S. T. In /eferogeneotis IVdrocowon Oxidation: Warren. B. K.. Ed.: American Chemical Sociely: Washinton DC. 1996: p 2.

2. Lec. I, H.: Joo. O. S.: Back. Y. S.: Yu. Y. H.: Iung. K. IJ. Bull Korean Chem. Soc. 2003.24. 1623.

3. Vaarkamp. M.: Ushikubo. T. Appl. Catal. Al General 1998. I7t. 90.

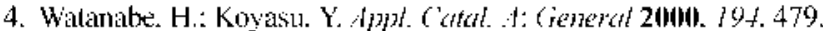

5. Millst. J. . M. M.: Roussel. H.: Pigamo. A.: [uboís. J. L.: Jumas. J. C. Appl Catal. A: General 2002. 232. 77.

6. Kong. J. 1.: Jung. J.S.: Choi, J.-G.: I LE. S. II. Appl. Caterl. A: General 2000. 20f. 241.

7. I.ee, S. Il. Jung J.S. Joo. J. U.: Myuug. V. S.: Jun. I. I I.: Choi. J-G. Appt Catal d: Generat 21012. 237.91.

8. Jutng. J.-S.: Ros. L.: O'Connor. C. J. J. Hat. (hem. 1992. 2. 829.

9. Lec. S. H.: Jutng. J. S.: Iung. D. W.: Kang. S. G.: Kimn. H. H. Bull. Korean Chem. Soc, 1996. $/ 7,541$.

10. WLl, 13.: Ren, 1..: O'Connor, C.. J.: Taung J.: Jung. J.-S.: Ferre, I.: Jamet. J. P. J. Hat. Res. 1994. 9.909.

1]. Arun. I': Vedeshuvar. A. G. Afal. Res. Butl. 1999. 3t. 203.

12. Elv: S. B.: Williams. P. A.: Buckley: A. N. Sirf Interfore Anal. 1996. 24. 641

13. Dissanasake. D.: I unstord. I. I .: Rossnek, M. P. J. Catal. 1993. 1.3. 286 .

14. Mallems. I: 1. J.: I loebink. J. 1[. 13.: Marin. (j. B. J. Catal. 1996. 160.222 .

15. Lacombe. S.: Geartet. C.: Mirodatos. C. f. Cutchl I994. /5/. 439

16. Cassids: T. I.: Pollastri. M.: Trifiro. F. J. Cuth. 1997. 172. 55.

17. I.ju. H.: lmoto. I1.: Shido. T.: I wasawa. Y. J. Catal. 2001. 200. 6)

18. ('rasselli. R. K. (atat. Todon 1909. +9. 141.

19. Nilsson. I.: Land-Canovas. A. R.: Hansen. S.: Andersson. A. I. Cutul, 1999. /86. 442.

20. Pillep. B.: Behrens. P.: Schubert. U.-A.: Spengler. J.: Krözinger. I1. J. Ph's: Chem. B 1999. 186. 442. 